特 集

\title{
温泉と健康
}

\section{Hot Spring (Onsen) and Health}

早坂 信哉*1

\author{
Shinya HAYASAKA
}

\begin{abstract}
This paper describes the outline of balneology and the hot spring effect for the human body. Hot springs (onsen in Japanese) are defined by certain criteria for the ingredients and hot water temperature. The thermal effect, one of the physical effects of hot springs, expand blood vessels to improve blood flow and recover fatigue. In addition, the chemical effect as mineral content of hot springs enhances the thermal effect. Japan has 21 health promotion facilities using hot springs which are approved by the national government, and the cost of using these facilities is recognized as medical expenses under the Japanese tax system. The development of measuring instruments and epidemiological surveys at hot springs are necessary for the development of balneology.
\end{abstract}

Keywords: hot spring, balneology, health promotion, thermal effect, bathing, Japan.

(2020 年 5 月 29 日受付)

\section{1 緒言}

温泉は本邦には27,000 を超える源泉があり[1], 日本 人は昔から温泉が身近な関係にあった。農閑期には多 くの農民が温泉地に長期滞在し, 疲れた体を癒す「湯 治」として温泉を活用していた。すなわち，日本人に とっては温泉を活用した健康づくりは昔から行ってい たことであった。

また，湯治まで本格的でないにしても，今でも休養 や気分転換などを目的に, 温泉は人気のリクリエーシ ヨンとなっている。旅行の「最も楽しみにしているも の」の第 1 位は「温泉」であり, 旅行者の $16.9 \%$ が温 泉を楽しみに旅行している $[2]$ 。また, 毎年の温泉宿へ の宿泊件数はのべ 1 億 2 千万泊を超えている $[1]$ 。温 泉は気持ちが良いもの, 健康に良いものとなんとなく 誰しもが感じているところであるが，本項では，医学 では温泉の人体への影響をどのように考えているのか を見ていきたい。また，現代では温泉を健康づくりに どのように活用しているのかを国の制度を踏まえて解 説していきたい。

\footnotetext{
連絡先： 早坂 信哉， $\bar{\top} 158-8586$ 世田谷区等々力 8-9-18, 東京都市大学人間科学部

総合研究所子ども家庭福祉研究センター

e-mail: hayasaka.ofuro@gmail.com

*1 東京都市大学
}

\section{2 温泉入浴の医学的な人体への影響}

温泉入浴の人体への影響は，まず大きく，温水に浸 かることそのものによる物理的作用と，温泉成分によ る化学的作用に分けられる。化学的作用は温泉水特有 の作用であるが，物理的作用は温泉に限らず，水道水 の沸かし湯であっても同様に作用するものである。

\section{1 物理的作用}

物理的作用はおおむ䃿下記の 5 つに分けて考えて いる。うち主な作用である(1)一(3)を解説する。

(1) 温熱作用

(2) 浮力

(3) 静水圧

(4) 粘性抵抗性

(5) 清浄作用

\section{1 .1 温熱作用}

\subsubsection{1 血流の改善}

温かい湯に浸かると初めに皮膚表面が温められる。 温められることによって血管が拡張し血流が良くなる。 血液は約 1 分間で全身を一周するので, 皮膚付近で温 められた血液は皮膚にだけとどまることはなく，身体 の奥深くにある内臓を含め全身を駆け巡る。その結果, 皮膚だけでなく温められた血液によって体内深くの核 心温又は深部体温といわれる体温も上がる。 
結果として全身の血流が改善することになる。血流 は人体が機能するうえで最も大切な体の仕組みである。 人体には 37 兆個もの細胞が生きているが，これらの 細胞が生きていくうえで最も大切な酸素や栄養分を運 んでくれるのは血液である。また細胞が生きていくと 結果として二酸化炭素や老廃物が出てくるが，これを 全身の各細胞から運び去ってくれるのも血液の役目で ある。この血流が良くなるということは，疲労回復や 細胞の再生を促す基本であり, また必須なことである。 つまり，温熱作用によって血液の流れが改善して新陳 代謝が改善するということである。

また，老化とは，言い換えれば血流の悪化がその根 本的な原因とも言え, 例えば心筋梗塞は心臓の回りの 血管の血流不良, 脳梗塞は脳内の血管の血流不良によ る結果である。いわゆる誛たきり高齢者に発生する「裖 瘡」(じょくそう, 床ずれ) は寝返りが打てないために, 腰やかかとなどの特定の箇所が長時間圧迫され，血流 が悪化したため起こる皮膚の潰瘍である。

\subsubsection{2 関節の軟化, 筋緊張の改善}

加齢が進むとじん帯（腱）などの柔軟性がなくなり， 関節の伸び縮みや動きが悪くなってくる。結果として 活動度が低下したり，体を動かすと痛みが発生する。 温泉で関節の周囲のじん帯が温まるとじん帯の柔軟度 が増して，関節の動きが良くなってくる。体を温めて からストレッチや運動を行うとより効果的である。ま た温まると筋肉の緊張も改善する。肩こりは肩に張る 僧帽筋などの緊張によるもので，筋肉の緊張が和らぐ と肩こりも改善する。

\subsubsection{3 疼痛の改善}

体を温めると慢性の痛みが改善することを経験的に 私たちは知っている。慢性の痛みがある人は痛みから くる不安などが悪循環となって, 痛みを感じる神経が いつも興奮している状態となる。このため, 他の人よ り痛みを感じやすいという悪循環に陥つている。温熱 を与えると, 関節や筀緊張の改善の他, C 線維の閾值 を上げ，痛み刺激に対する神経の過敏性を改善させる ことが分かっている[3]。このことから，特に慢性の痛 みに効果があると考えられている。

\subsubsection{4 温度の違いによる人体への影響}

浴槽の湯の温度はわずかな差で人体一及ぼす影響は違 ってくる。人体のバランスを取っている自律神経は交
感神経と副交感神経で成り立っているが，38～40 $\mathrm{C}$ ま でのぬる湯ならリラックスの副交感神経が， $42^{\circ} \mathrm{C}$ 以上 の熱い湯だと興奮状態の交感神経が刺激される。温度 が $1^{\circ} \mathrm{C}$ 異なるだけで，自律神経を介して人体へ与える 影響が大きく変わってくる[4]。

\subsection{2 浮力}

家庭のような小さな湯船であっても，湯（水）に浸 かることで湯から浮力を受けている。浮力は水面下に 浸かっている人体の体積に比例し, 首まで浸かると体 重はおよそ 10 分の 1 になる。普段はあまり意識しな いが，お風呂に入ってみると体がふわふわと水に浮か ぶのはこの浮力によるものだ。

地球上に生きている限り, 重力の束縛からは逃れる ことはできない。体重が $60 \mathrm{~kg}$ の人が地上で座ってい る時, $60 \mathrm{~kg}$ の体重を支えるように腰や首の筋肉が無意 識のうちに緊張している。しかし，お風呂に入って首 まで浸かると体重はわずか $6 \mathrm{~kg}$ となり，体を支える筋 肉の緊張はほとんど必要なくなる。地球上において重 力から解放される唯一の場所がお風呂であり，私は浴 室が究極のリラックス空間であると人に説明している が，これが理由である。

\subsection{3 静水圧}

小さい湯船であっても，水の深さがあれば水圧が発 生する。動きのない湯船にたまった水による圧力を特 に静水圧という。 $50 \mathrm{~cm}$ の深さの浴槽の底 $10 \mathrm{~cm}$ 四方

$\left(100 \mathrm{~cm}^{2}\right)$ に $5 \mathrm{~kg}$ 重の力がかかっている。この水圧は, 水中にある人体にも作用し人体を締め付ける。特に浴 槽の一番深いところに位置する下肢を強く圧迫し，下 肢にたまった血液や体液を心臓に押し戻し，血流を改 善しむくみを解消する。一方，肺や心臓に疾患のある 人にとっては，水圧によって胸が圧迫されたり，下半 身の血液が大量に心臓に押し戻されることによって， 肺や心臓に負担となり息苦しさを感じることがある。 よく半身浴が体に良いと言われる理由はここにある。

\section{2 化学的作用}

\section{2 .1 温泉の化学的作用}

水道水と異なり，温泉にはイオン類をはじめとして 様々な成分が含まれている。自然界に湧出する温水や 鉱水は温泉法によって一定の成分を含む場合, 又は $25^{\circ} \mathrm{C}$ 以上の温度を有するものであると定義されている。 
また，酸性やアルカリ性といった液性と言われる性質 も様々である。これらの成分や液性が，その温泉に入 ることによって人体へ様々な影響を与えるが, これを 化学的作用（又は薬理作用）と言う。

温泉水の各種成分は皮膚を通して体内に吸収される ことがこれまでの様々な研究から明らかになっている。 硫黄を含む温泉では，その成分である硫黄がイオンの 形で皮膚から吸収され人体の一部となることが実験的 にも証明されている。その他，ヨード，鉄，ナトリウ ム, カルシウム, クロールなども皮膚より吸収される ことが知られている。また, 温泉水中に含まれるガス 成分である炭酸も皮膚より効率良く吸収され, 結果と して血管を拡張させ，血流を改善させる。最近，街中 で見る日帰り温浴施設等にも人工炭酸泉が設置されて いる例もあるが，同様にこうした効果が期待できる。 またナトリウムを多く含む温泉では, 浴後も塩類が皮 膚に付着し皮膚からの水分の蒸発を防ぎ, 保温効果を 発揮する。また, 液性で言えば酸性泉は強い殺菌効果 を示し，アルカリ性であれば皮膚表面の古い角層を除 去し皮膚の代謝を高める作用があると考えられている。

一方, 人体の皮膚は強力なバリア機能を有している。 人体の外界, 寸なわち普段人が生活している環境には 目に見えなくとも無数の雑菌やウイルス, また化学物 質が存在する。これらの微生物類や化学物質がすべて 皮膚から吸収されたのでは, 人はたちどころに感染症 や各種中毒症に罹患してしまうことになる。しかし， 我々は何事もなく生活できるのは, 皮膚のバリア機能 によって人体内一の様々な微生物, 物質の侵入を防い でいるからにほかならない。温泉成分による化学的作 用は存在するが，温泉に含まれる成分がすべて多量に 人体に吸収されるわけではないということを知ってお く必要がある。

\section{3 温泉 $\cdot$ 療養泉の定義と種類}

「温泉」という言葉は当たり前のように日常的に用 いられているが，そもそも「温泉」とは，なにを指寸 のだろうか。温泉は, 1948 年に制定された「温泉法」 により, 地中からゆう出する温水, 鉱水及び水蒸気そ の他のガス (炭化水素を主成分とする天然ガスを除く。) で，温度又は物質を有するものと定義されている[5]。 （Table 1，[5]の原文のままのため日本語）
Table 1 Definition of hot spring in Japan. Original text was written in Japanese Law[5].

\begin{tabular}{|c|c|}
\hline \multirow{3}{*}{\begin{tabular}{|l} 
1.温度（温泉源から採取されるときの温度） 摂氏2 \\
2.物質（以下に掲げるもののう、いずれか一つ） \\
物質名
\end{tabular}} & 安以上 \\
\hline & \\
\hline & 含有量（1kg中） \\
\hline 溶存物質（ガス性のものを除く。） & 総量 $1,000 \mathrm{mg}$ 以上 \\
\hline 遊離炭酸（CO2）（遊離二酸化炭素） & $250 \mathrm{mg}$ 以上 \\
\hline リチウムイオン $(\mathrm{Li}+)$ & $1 \mathrm{mg}$ 以上 \\
\hline ストロンチウムイオン $(\mathrm{Sr} 2+)$ & $10 \mathrm{mg}$ 以上 \\
\hline バリウムイオン $(\mathrm{Ba} 2+)$ & $5 \mathrm{mg}$ 以上 \\
\hline フェロ又はフェリイオン $(\mathrm{Fe} 2+, \mathrm{Fe} 3+) \quad($ 総鉄イオン $)$ & $10 \mathrm{mg}$ 以上 \\
\hline $\begin{array}{l}\text { 第一マンガンイオン }(\mathrm{Mn} 2+) \\
\text { (マンガン (II ) イオン) }\end{array}$ & $10 \mathrm{mg}$ 以上 \\
\hline 水素イオン $(\mathrm{H}+)$ & $1 \mathrm{mg}$ 以上 \\
\hline 臭素イオン $(\mathrm{Br}-) \quad$ (臭化物イオン) & $5 \mathrm{mg}$ 以上 \\
\hline 沃素イオン（I-）（ヨウ化物イオン） & $1 \mathrm{mg}$ 以上 \\
\hline ふっっ素イオン (F-) $\quad($ フッ化物イオン) & $2 \mathrm{mg}$ 以上 \\
\hline ヒドロひ酸イオン (HASO42-) $\quad$ (ヒ酸水素イオン $)$ & $1.3 \mathrm{mg}$ 以上 \\
\hline メタ亜ひ酸（HASO2） & $1 \mathrm{mg}$ 以上 \\
\hline 総硫黄(S) [HS-+S2O32-+H2Sに対応するもの] & $1 \mathrm{mg}$ 以上 \\
\hline メ夕ほう酸 $(\mathrm{HBO} 2)$ & $5 \mathrm{mg}$ 以上 \\
\hline メタけい酸（H2SiO3） & $50 \mathrm{mg}$ 以上 \\
\hline 重炭酸そうだ（NaHCO3）（炭酸水素ナトリウム） & 340mg以上 \\
\hline ラドン（Rn) & $\begin{array}{l}20 \\
\text { (百億分の } 1 \\
\text { キュリー単位) 以上 }\end{array}$ \\
\hline 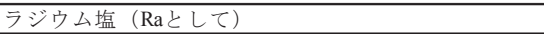 & 1億分の $1 \mathrm{mg}$ 以上 \\
\hline
\end{tabular}

すなわち，温度，又は含有する物質が一定の基準を 満たしていればよいということになり，また液体とし ての温水や鉱水だけでなく, 水蒸気その他のガスまで も「温泉」となることに注意を要する。

その温泉 (水蒸気その他のガスを除く。) のうち, 特 に治療の目的に供しうるものを療養泉としており, 湧 出時の温度が $25^{\circ} \mathrm{C}$ 以上, 又は遊離二酸化炭素が $1000 \mathrm{mg} / \mathrm{kg}$ 以上など, 定められた一定の物質を有する ものと定義されている。これらの物質を含むことで,

「療養泉」とする, と定義づけた医学的根拠は判然と していない。

\section{4 療養泉における「適応症」}

療養泉は主な含有成分に基づいて単純温泉のほか 大きく 9 つに分類されている。どんな温泉がどんな状 態の療養に向くのかが環境省から「適応症」として定 められている。泉質を問わず療養泉に共通するのが「一 般的適応症」, 泉質別に決められているのが「泉質別適 応症」である。適応症には浴用と飲用がある。一般的 適応症 (浴用) は以下の通りである[6]。「筋肉又は関節 の慢性的な痛み又はこわばり（関節リウマチ，変形性 関節症, 腰痛症, 神経痛, 五十肩, 打撲, 捻挫などの 慢性期), 運動麻痺における筋肉のこわばり, 冷え性, 末梢循環障害，胃腸機能の低下（胃がもたれる, 腸に ガスがたまるなど), 軽症高血圧, 而糖能異常（糖尿 
病), 軽い高コレステロール血症, 軽い喘息又は肺気 腫，痔の痛み，自律神経不安定症，ストレスによる 諸症状（睡眠障害，うつ状態など）, 病後回復期，疲 労回復, 健康増進」と広範囲に及ぶ。

これらの適応症は 2014 年 7 月に 32 年ぶりに見直し がなされたものである。前回の適応症の作成は 1982 年 であり, その後, 医学的研究がなされ様々な温泉の効 果に関する結果が示されたため, その研究結果を踏ま えて見直しがなされた。したがって，今回環境省から 示された適応症は科学的根拠に基づくものと言えるも のである。

一方，泉質別適応症からはそれぞれの療養泉の特徵 がつか夕にくい。療養泉の理解のために, 以下にそれ ぞれの療養泉の特徵を箇条書きにして記す。

4.1 単純温泉

温泉水 $1 \mathrm{~kg}$ 中の溶存物質量（ガス性のものを除く） が 1,000mg 未満で，涌出時の泉温が $25^{\circ} \mathrm{C}$ 以上のもの。 溶け込んでいる成分が少ないため単純温泉とされるが, 温泉によって溶け込んでいる物質が異なる。刺激が少 なく，万人向け。日本で一番多い泉質である。

\section{2 塩化物泉}

温泉水 $1 \mathrm{~kg}$ 中に溶存物質量（ガス性のものを除く） が 1,000mg 以上あり，陰イオンの主成分が塩化物イオ ンのもので俗に「熱の湯」と呼ばれる，保温効果の高 い温泉。単純温泉に次いで 2 番目に多い泉質である。

\section{3 硫酸塩泉}

温泉水 $1 \mathrm{~kg}$ 中に溶存物質量（ガス性のものを除く） が 1,000mg 以上あり, 陰イオンの主成分が硫酸イオン。 塩化物泉に近く保温効果が高い。

\section{4 炭酸水素塩泉}

温泉水 $1 \mathrm{~kg}$ 中の溶存物質量（ガス性のものを除く） が $1,000 \mathrm{mg}$ 以上あり，陰イオンの主成分が炭酸水素イ オンのもので，皮膚の角質を軟化させ，污れを取る。 湯上り感がさっぱりしていて俗に「美人の湯」と言わ れる泉質である。

\section{5 二酸化炭素泉}

温泉水 $1 \mathrm{~kg}$ 中に遊雛炭酸（二酸化炭素）が $1,000 \mathrm{mg}$ 以上含まれているもので，二酸化炭素が皮膚から吸収 されて血管拡張作用がある。血管拡張作用の機序は血
管内皮の一酸化窒素の増加によるものと推定されてい る。

\section{6 含鉄泉}

温泉水 $1 \mathrm{~kg}$ 中に総鉄イオン（鉄 II 又は鉄III）が $20 \mathrm{mg}$ 以上含まれているもので赤褐色の色は鉄イオンの酸化 されたことよるもの。やや皮膚へ刺激がある。2014 年 の通知により，以前この泉質に与えられていた「月経 障害」の適応症は削除された。

\section{7 含よう素}

温泉水 $1 \mathrm{~kg}$ 中によう化物イオンが $10 \mathrm{mg}$ 以上含有す るもので 2014 年から新しく療養泉になった。飲用で 高コレステロール血症を抑制する。

4.8 酸性泉

温泉水 $1 \mathrm{~kg}$ 中に水素イオンが $1 \mathrm{mg}$ 以上含まれている もので，酸性が強く，殺菌力が強い。

\section{9 硫黄泉}

温泉水 $1 \mathrm{~kg}$ 中に総硫黄が $2 \mathrm{mg}$ 以上含まれているも ので殺菌力が強い。卵の腐った臭いが特徵。血管拡張 作用がある。

\subsection{0 放射能泉}

温泉水 $1 \mathrm{~kg}$ 中にラドンが $30 \times 10^{-10}$ キュリー以上 $(8.25$ マッへ単位以上) 含まれているもの。人体に悪影響を及 ぼすと考えられがちだが，放射線量は少なく，これま で放射能泉の放射線による健康障害の報告はない。海 外では疼痛緩和に利用されている。

\section{5 温泉を活用した健康増進施設}

ヨーロッパ諸国ではドイツやフランスのように温 泉療養が医療として認められ，健康保険が適応となっ ている国がある。しかし，我が国において，温泉療養 には健康保険の適応は認められていない。すなわち健 康保険上は温泉療養は医療として認められていないの が現状である。しかし，あまり知られていないが，一 定の基準を満たした温泉利用型健康増進施設において 温泉療養を行うことで，その利用料や交通費を医療費 として税制上認められる制度が我が国にはある。この 制度を用いて温泉療養を行えば医療費控除を行うこと ができ，結果，節税になるということである。本項で はこの制度について説明する。 


\section{1 厚生労働大臣が認定する健康増進施設}

健康増進施設とは，厚生労働省が国民の健康づくり を支援する上で必要な運動施設として, 設備要件や人 的要件等の基準を満たした適切な運動施設を認定する 制度で，1988 年 11 月に当時の厚生省によって創設さ れた[7]。現在では，A.運動型健康増進施設，B.温泉利 用型健康増進施設，C.温泉利用プログラム型健康増進 施設，の 3 類型の施設がある。

このうち， B の温泉利用型健康増進施設とは，上記 の要件等基準を満たし温泉を利用した健康つくりを図 る施設であり，1）温泉が脳血管障害, 糖尿病, 高血圧 等の生活習慣病に一定の効果があり, 生活習慣病対策 の一環として温泉療養の普及を図る，2）認定施設は認 定要件に照らして, 健康づくり, 疾病の予防等に対応 できる体制を整えており，疾病対策として望ましい利 用促進を図ることを目的としている。2020 年 4 月現在 全国で 21 か所の施設がある。温泉利用型健康増進施 設として認定される設備要件としてはかけ湯, 半身浴・ 全身浴, 圧注浴, 寝湯, サウナなど 5 種類の浴槽を備 え，かつトレーニングジムなどの運動設備があること である。また人的要件として健康運動指導士，温泉利 用指導者の配置が義務ら゙けられている。

一方，A.運動型健康増進施設は運動を主体とした施 設であり温泉設備はない。施設数は現在 344 か所であ る。また C.温泉利用プログラム型健康増進施設は現在 28 か所あり，温泉施設を備えてはいるが，温泉利用型 健康増進施設と比較して施設要件や人的要件が緩く, その代わりに利用料等も医療費控除の対象とならない。
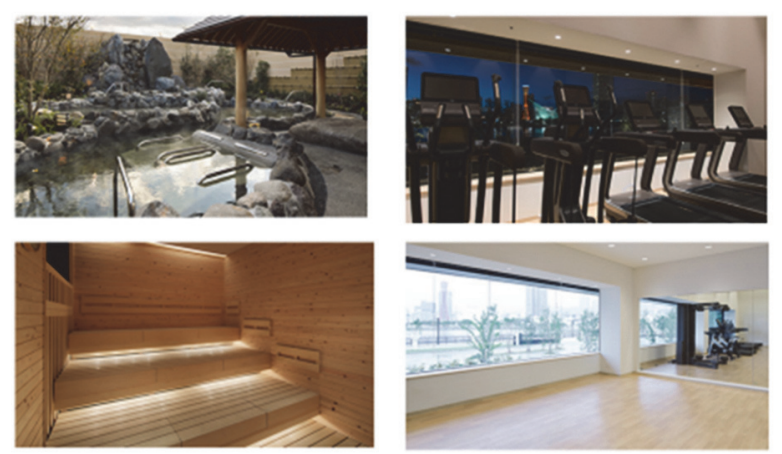

Fig. 1 An example of health promotion facility using hot springs: Kobe Minato Onsen Ren.
5.2 温泉利用型健康増進施設利用者への利点

この施設において一定の手続きを行えば施設の利用 料金及び施設までの往復の交通費等が所得税の医療費 控除の対象となるのが利用者にとっても大きな利点で ある。手続きは若干煩雑となるが，温泉療法医等の医 師より温泉療養指示書を発行してもらい，概数 1 ケ月 に 7 回以上の温泉療養を行った場合がその適応となる。

同施設の特徵は，前述の通り有資格者と温泉を利用 した各種の入浴設備，及び運動設備が総合的に配置さ れていることである。また，温泉療法の知識・経験を 有する温泉療法医等の医師のいる医療機関と提携し, 温泉利用指導者資格を持ったスタッフが，医師作成の 温泉療養指示書に従って入浴指導を行い，安全管理や 応急措置，生活指導全般を行うことができる。

利用者へ利点がある制度である一方，医師への受診 や手続きが煩わしいといった点や，施設側も有資格者 をスタッフとして雇用する必要があり，十分に活用さ れているとは言い難いのが現状である。

\section{6 温泉医学の研究の現状と課題}

温泉に関する医学研究は，まだ現代医学が十分では ない戦前には隆盛を誇り，筆者も理事を務めている一 般社団法人日本温泉気候物理医学会は，1934 年に東京 大学医学部内科物理療法学教室，日本温泉協会学術部 を母体として結成され，同時に日本医学会に第 15 番 目の学術団体に加入し, 今日に至る長い歴史を誇る学 会である。他にもいくつか「温泉」と名前のつく学会 はあるが，医学系の温泉に関する学会はこの学会だけ である。現在も 1,800 名の会員を擁しており，その多 くは医師である。

以前は, 北海道大学, 東北大学, 群馬大学, 岡山大 学，九州大学，鹿児島大学が温泉地に分院を持ってお り，活発に温泉医学に関寸る研究が進められた。しか し，1990 年代後半からこれらの分院の統廃合が進み, 現在は九州大学別府病院を残すのみとなった。そのた め, 温泉地の大学が自分の施設内の温泉を用いて研究 を行うスタイルから，研究者が温泉に出向く，あるい は疫学的な研究へと変換せざるを得なくなった。筆者 自身は温泉を有する自治体(静岡県熱海市) とともに住 民の健康と温泉利用の関連を疫学的に調査し，自宅で 温泉を利用している高齢者は介護状態が悪化しにくい ことを報告した[8]。世界有数の温泉国ながら，我が国 の温泉医学の研究環境は変化しており，このような状 
況を打開するための方策の 1 つとして, 温泉現地で研 究として人体から生体情報を取得するための機器の小 型化，簡便化，IoT 化が望まれている。

以上，温泉の人体一与える作用や最近の温泉医学に 関する動向を述べた。この分野にも読者の先生方に興 味を持っていただけると幸いである。

（本論文は文献[9]を元に改変して執筆した。）

\section{参考文献}

[1] 環境省, 平成 30 年度温泉利用状況

https://www.env.go.jp/nature/onsen/pdf/2-4_p_1.pdf, (参照 2020-5-26).

[2] 公益財団法人日本交通公社，旅行年報，2015.

[3] 松元, 温泉入浴と中枢および末梢神経機能, 新温泉医学, 日本温泉物理医学会, 東京, pp. 204-211, 2004.

[4] 光延, 谷崎, 温泉入浴と自律神経機能, 新温泉医学, 日 本温泉物理医学会, 東京, pp. 212-218, 2004.

[5] 環境省, 温泉の定義, https://www.env.go.jp/nature/onsen/point/(参照 2020-5-26).

[6] 環境省自然環境局長通知, 環自総発第 1407012 号 平成 26 年 7 月 1 日, 「温泉法第 18 条第 1 項の規定に基づく 禁忌症及び入浴又は飲用上の注意の掲示 等の基準」及 び「鉱泉分析法指針（平成 26 年改訂）」について, https://www.env.go.jp/nature/onsen/docs/kyokucho.pdf, (参照 2020-5-26).

[7] 厚生労働省, 健康増進施設認定規定, 厚生省告示第 273 号, 1988 年 11 月 29 日, 厚生労働省告示第 158 号, 2016 年 3 月 31 日改正.

[8] Hayasaka S, Uchida M, Hattori M, Watanabe H, Ojima $\mathrm{T}$, Association between having a hot spring water supply in the home and prevention of long-term care, Complem entary Therapies in Clinical Practice, Vol. 33, pp. 142-1 48, 2018.

[9] 早坂, 第 3 章 温泉による健康への効果, 温泉・森林浴 と健康, 大修館, 東京, pp. 35-52, 2019. 